\title{
ICT as an Instrument of Enhanced Banking System
}

\author{
Emmanuel N. Ekwonwune1, Deborah U. Egwuonwu², Leticia C. Elebri'1, Kanayo K. Uka3 \\ ${ }^{1}$ Department of Computer Science, Imo State University, Owerri, Nigeria \\ ${ }^{2}$ Department of Computer Science, Abia State Polytechnic, Aba, Nigeria \\ ${ }^{3}$ Department of ICT, Imo State University, Owerri, Nigeria \\ Email: ekwonwuneemmanuel@yahoo.com
}

How to cite this paper: Ekwonwune, E.N., Egwuonwu, D.U., Elebri, L.C. and Uka, K.K. (2017) ICT as an Instrument of Enhanced Banking System. Journal of Computer and Communications, 5, 53-60. http://dx.doi.org/10.4236/jcc.2017.51005

Received: November 29, 2016

Accepted: January 14, 2017

Published: January 17, 2017

Copyright $\odot 2017$ by authors and Scientific Research Publishing Inc. This work is licensed under the Creative Commons Attribution International License (CC BY 4.0).

http://creativecommons.org/licenses/by/4.0/ (c) (i) Open Access

\begin{abstract}
This study investigated the role of Information and Communications Technology in an enhanced banking operation using Diamond Bank Plc, Imo State as a case study. The study was motivated by the fact that most industries, financial institutions rely on gathering, processing, analyzing, and providing information in order to meet the needs of customers. It was based on data primarily, collected from both the primary and secondary sources which seek to investigate role of Information and Communications Technology in the banking industry. This piece of work, through direct investigation, interviews and questionnaires used to examine the role of Information and Communication Technology, plays in the banking industries and how it has affected the employment generation in the industries. It was gathered that ICT has positively affected the bank, the employees and the customers. The result also shows the application has improved banking services, maintained high level of proficiency and efficiency, reduced the long time spent on queues and brought about increase in employment opportunities.
\end{abstract}

\section{Keywords}

ICT, Banks, Information Technology, Efficiency, Technological Innovation

\section{Introduction}

According to Margaret Rouse [1], ICT (Information and Communications Technology or Technologies) is an umbrella term that includes any communication device or application, encompassing: radio, television, cellular phones, computer and network hardware and software, satellite systems and so on, as well as the various services and applications associated with them, such as videoconferencing and distance learning. According to Wikipedia [2], Informa- 
tion Technology (IT) is the application of computers and internet to store, retrieve, transmit, and manipulate data, or information, often in the context of a business or other enterprise. Technological innovations have enabled the industry to open up efficient delivery channels. IT has helped the banking industry to deal with the challenges the new economy poses. Technology is also changing the supervisory and regulatory landscape. It is creating new tools for supervisors and new supervisory challenges.

Today's business environment is very dynamic and undergoes changes as a result of technological innovations, increased awareness and demand from customers. According to Ekwonwune and Dike [3], Business organization, especially the banking industry, operates in a complex and competitive environment characterized by these changing conditions and highly unpredictable economic climates. According to them, Information Communications Technology (ICT) is at centre of this global change. Laudon and Laudon [4] contend that managers cannot ignore information systems because they play a critical role in the organization. They point out that the cash flow of most fortune companies is linked to information systems.

The application of Information and Communications Technology concepts, techniques policies and implementation strategies to banking services has become a subject of fundamental importance and concern to all banks and indeed a prerequisite for local and global competitiveness. Information and Communications Technology directly affects how managers decide, how they plan and what products and service are offered in the banking industry. Ekwonwune and Dike still maintain that Information Technology has continued to change the way banks and their corporate relationships are organized worldwide, and the variety of innovative devices available to enhance the speed and quality of service delivery.

\subsection{Statement of Problem}

Lack of knowledge and inappropriate applications of ICT tools and techniques has resulted to poor performance of Diamond Bank Plc and this has led to low profitability of the organization. The organization lacks the technical knowhow and the necessary tools in the day-to-day operations. They believe that Information and Communications Technology has brought about the use of computer system in all areas of human endeavors and that this application will lead to retrenchment or loss of jobs.

In the light of some of these observed and anticipated problems that befall this organization, there is a need to adopt the necessary ICT tools that enhance proficiency, productivity, efficiency and high level of profitability and increased level of employment generations.

\subsection{Objectives of Study}

The objectives of the study are as follows:

1) To assess the impact of Information and Communications Technology in the 
Diamond Bank Plc.

2) To assess the perception of bank, employees and customers towards the implementation of information and communications technology.

\subsection{Research Questions}

In the light of the above, the following research questions are posed:

1) How does the application of ICT tools in banking services maintain high level of efficiency and proficiency?

2) Has the introduction of Information and Communications Technology improved the banking services?

3) Has the use of computers and other ICT tools reduced the long time delay spent on queue by customers in the bank?

4) Has there been any change witnessed on the employment scenario with the presence of Information and Communications Technology?

\subsection{Research Hypotheses}

Two research hypotheses were designed to test the role of information technology in the banking industries. The null hypothesis $\mathrm{H}_{\mathrm{o}}$ put the statement succinctly, while the alternative hypothesis $\mathrm{H}_{1}$, determines the validity of the statement. The details were given as follows:

$\mathrm{H}_{1 \mathrm{~A}}$ : ICT has brought about increased efficiency, effectiveness and increased productivity in the banking Industries

$\mathbf{H}_{10}$ : ICT has not brought about increased efficiency, effectiveness and increased productivity in the banking Industries

$\mathrm{H}_{2 \mathrm{~A}}$ : ICT has brought about increase in employment opportunities in the banking industries

$\mathrm{H}_{2 \mathrm{O}}$ : ICT has not brought about increase in employment opportunities in the banking industries

\section{Theoretical Background}

Advancement in information and communication technology has positively impacted on the efficient and effective implementation of banking services and products.

Hassan [5] posits that advances in technology are allowing for delivery of banking products and services more conveniently and effectively than ever before - thus creating new bases of competition. Banks had gained a vital competitive advantage by direct marketing and good customer care delivery as a result, which has helped increase market share. He continued, "the advantages accruing from ICT are three-direction: to the customer, Bank \& Employee”.

Hassan [5] noted that the customer's benefits included: remote banking, selfinquiry facility and electronic banking facilities among others adding that banks had a lot to gain from implementing ICT facilities. Such gains included Internet banking, good feedback Mechanism and happy customer goodwill, inter-alia. He posits that bank employee's productivity and timely delivery of business opera- 
tions had all improved as a result.

Hassan [5] also maintained that the internet particularly as an information super highway of a global economic market place has facilitated the contribution of ICT in the implementation of banks and their operations-through the WorldWide-Wide (WWW) an internet protocol.

Nevertheless, it was Rahman, [6] that stressed some of these advantages of ICT to include:

1) Technology has opened up new markets, new products, new services and efficient delivery channels for the banking industry. Online electronics banking, mobile banking and internet banking are just a few examples.

2) Information Technology has also provided banking industry with the wherewithal to deal with the challenges the new economy poses. Information technology has been the cornerstone of recent financial sector reforms aimed at increasing the speed and reliability of financial operations and of initiatives to strengthen the banking sector.

3) Opening up of new market, services and delivery channels.

4) Solution to economics challenges, financial reform stages.

5) Increase in financial activities and good customer delivery services as in ATM provision among other.

\section{Banking Networking In Nigeria}

Nweke Remmy [7] observed that in Nigeria our traditional payment model was the "brick and motar" system which was the same as expansion of bank branch networks necessitated by compulsory appearance of consumers in the banks to consummate transactions. This "brick \& motar" system was Nigeria's traditional payment model characterized by many branch network and long queues of customer for transactional purpose. He saw insecurity, inconveniences, high cost of transactions, cumbersome and high business risk as some of its challenges. $\mathrm{He}$ was however happy that the presence of ICT in today's banking operations has reduced such problems by way of reducing the cost of transaction and increasing "the speed of services".

\section{Research Design}

Descriptive Survey Design was used. The research was a survey which involved the sampling of selected branches of Diamond Bank in the South Eastern part of the country by means of copies of questionnaire structured for this purpose. These branches included the banks, employees and the customers which constituted the respondents to be studied and their responses provided the data to analyze this report.

\subsection{Population and Sample Size Determination}

The population of the study was made up of 579 staffs of the organization's staff and customers selected from the South Eastern part of Nigeria working in Diamond Bank. A sample size of 550 was selected from the entire population using 
the statistical relationship by Ekezie [8] as a guide. Thus, we have:

$$
n=\frac{N}{1+N_{e}^{2}}
$$

where $N=$ population size; $e=$ Error term; $n=$ the required sample size [8].

\subsection{Data Analysis}

The data collection from the respondents was put into tables and the response frequencies were converted to percentage. Therefore, the weighted Mean Average was the statistical tool used to analyze the data.

This section is the analysis and presentation of the data collected from the respondents. The data were presented in tables and the response frequencies were converted to percentages. The analysis was based on the 550 copies of questionnaire administered to and retrieved from the respondents. The section opens with demographic data of the respondents, which highlights the gender, age, and job experience of respondents.

The measuring instruments that were utilized in this study would be of two forms: Questionnaire and Oral Interview of staff of the organizations that use ICT tools. Response to each item in the scale would be scored as in Fido Gayford five point Likert scale responses of Strongly Agree (SA), Agree (A), Undecided (U), Strongly Disagree (SD) and Disagree (D). The response options are weighted or scored in such a way that a higher value indicates a more positive/ intense response or attitude as follows: Strongly Agree $(\mathrm{SA})=5$, Agree $(\mathrm{A})=4$, Strongly Disagree $(\mathrm{SD})=3$, Disagree $(\mathrm{D})=2$ and Undecided $(\mathrm{U})=1$.

In this piece of work, data were collated, classified, categorized and analysed as shown in the tables below. Using the set of graduated options, an individual is expected to indicate his degree of agreement or disagreement in response to all statements. These responses are weighted (i.e. assigned numerical values) and by summing up an individual response to all statements, a total score is obtained. This total then provides an estimate of that person's standing on the variable being measured. According to Nworgu [9], the construction of this scale entails generating a list of statements about what is being measured and providing a set of graduated responses options.

Here also, the total percentage and mean of data were calculated. The Weighted Mean is given by

$$
X_{w}=\frac{\sum_{i=1}^{n}\left(F_{i} W_{i}\right)}{\sum_{i=1}^{n} W_{i}}
$$

where $F_{i}=$ Frequency of the responses; $W_{i}=$ The Weighted Mean of the responses.

Table 1 shows that 324 respondents (58.8\%) were males and 226 (41.2\%) were females. In terms of age, $16.2 \%$ were below the age of 20 years; $16.9 \%$ were 20 to 24 years; $14.7 \%$ were 25 to 29 years; $15.5 \%$ were 30 to 34 years; $22.4 \%$ were 35 to 39 years while $14.4 \%$ were above 40 years. In terms of job experience, $18 \%$ had 
worked for less than two years; $22 \%$ had worked from 2 to 4 years; $20.5 \%$ had worked from 5 to 7 years; $24.4 \%$ had worked from 8 to 10 years while $15.1 \%$ had worked above 10 years.

Table 2 displays that 278 (50.5\%) Strongly Agree; 132 (24\%) Agree; 72 (13.1\%) Highly Disagree; 40 (7.3\%) Disagree; while 28 (5.1\%) were Undecided. The application of ICT tools in the banking services maintains high level of efficiency and proficiency.

Table 3 shows 271 (49.3\%) of the respondents strongly agreed that application of IT tools has improved the banking services of Diamond Bank Plc. However, $146(26.5 \%)$ Agreed to the assertion and 68 (12.4\%) strongly disagreed to the statement, 34 (6.2\%) disagreed while 31 (5.6\%) were Undecided.

Similarly, Table 4 and Table 5 show the analyses of the responses on determination of reduced time spent on long queues and Employment Generation by ICT tools respectively.

Answering Research Questions: Research question 1 was answered through the use of item 1 in the question, "How does the application of ICT tools in

Table 1. Demographic data of respondents.

\begin{tabular}{|c|c|c|c|c|}
\hline $\mathrm{S} / \mathrm{n}$ & Attribute & Option & Frequency & Percentage (\%) \\
\hline \multirow{3}{*}{1} & \multirow{3}{*}{ Gender } & Male & 324 & 58.8 \\
\hline & & Female & 226 & 41.2 \\
\hline & & Total & 550 & 100 \\
\hline \multirow{7}{*}{2} & \multirow{7}{*}{ Age (yrs) } & $<20$ & 89 & 16.2 \\
\hline & & $20-24$ & 93 & 16.9 \\
\hline & & $25-29$ & 81 & 14.7 \\
\hline & & $30-34$ & 85 & 15.5 \\
\hline & & $35-39$ & 125 & 22.4 \\
\hline & & 40 and above & 79 & 14.4 \\
\hline & & Total & 550 & 100 \\
\hline \multirow{6}{*}{3} & \multirow{6}{*}{ Job experience } & $<2$ & 99 & 18 \\
\hline & & $2-4$ & 121 & 22 \\
\hline & & $5-7$ & 113 & 20.5 \\
\hline & & $8-10$ & 134 & 24.4 \\
\hline & & Above 10 & 83 & 15.1 \\
\hline & & Total & 550 & 100 \\
\hline
\end{tabular}

Source: Field work 2016.

Table 2. Efficiency of ICT tools in banking system.

\begin{tabular}{ccccccc}
\hline Response & Strongly Agree & Agree & Strongly Disagree & Disagree & Undecided & Total \\
\hline Observed Frequency & 278 & 132 & 72 & 40 & 28 & 550 \\
Percentage (\%) & 50.5 & 24 & 13.1 & 7.3 & 5.1 & 100 \\
\hline
\end{tabular}

Source: Field work 2016. 
Table 3. Improvement of ICT on banking services.

\begin{tabular}{ccccccc}
\hline Response & Strongly Agree & Agree & Strongly Disagree & Disagree & Undecided & Total \\
\hline Observed Frequency & 271 & 146 & 68 & 34 & 31 & 550 \\
Percentage (\%) & 49.3 & 26.5 & 12.4 & 6.2 & 5.6 & 100 \\
\hline $\begin{array}{l}\text { Source: Field work 2016. } \\
\text { Table 4. Reduction of longtime delay }\end{array}$ & spent on queues. & & & \\
\hline Response & Strongly Agree & Agree & Strongly Disagree & Disagree & Undecided & Total \\
\hline Observed Frequency & 280 & 130 & 62 & 48 & 30 & 550 \\
Percentage (\%) & 50.9 & 23.6 & 11.3 & 8.7 & 5.5 & 100 \\
\hline
\end{tabular}

Source: Field work 2016.

Table 5. Generation of employment by ICT tools.

\begin{tabular}{ccccccc}
\hline Response & Strongly Agree & Agree & Strongly Disagree & Disagree & Undecided & Total \\
\hline Observed Frequency & 275 & 135 & 54 & 34 & 52 & 550 \\
Percentage (\%) & 50 & 24.5 & 9.8 & 6.2 & 9.5 & 100 \\
\hline
\end{tabular}

Source: Field work 2016.

Table 6. Summary of results.

\begin{tabular}{ccc}
\hline Research Questions & Weighted Mean Xw & Remark \\
\hline 1 & 4.08 & Agreed \\
2 & 4.08 & Agreed \\
3 & 4.06 & Agreed \\
4 & 4.03 & Agreed \\
\hline
\end{tabular}

Source: Field work 2015.

banking services maintain high level of efficiency and proficiency?". Table 2 shows that out of 550 respondents, 278 (50.5\%) Strongly Agreed, 132 (24\%) Agreed, 72 (13.1\%) Strongly Disagreed, 40 (7.3\%) Disagreed while 28 (5.1\%) were Undecided that application of ICT in the banking services has high level of efficiency and proficiency. Similarly research Question 2 was answered using item 2 in the questionnaire. Table 3 explains this answer. It shows that 271 (49.3\%) Strongly Agreed, 146 (26.5\%), 68 (12.4\%) Strongly Disagreed, 34 (6.2) Disagreed and 31 (5.6\%) were undecided that applications of ICT tools has improved the banking services of Diamond Bank Plc. Using this same analysis, Research Question 3 and 4 are shown in Table 4 and Table 5 respectively.

\section{Decision:}

Table 6 shows the summary of results. It shows that for all the research questions posed to the respondents as respective subject matter, there in agreement to the arguments raised.

That is they all agreed that:

1) Application of ICT tools in banking services maintains high level of proficiency and efficiency. 
2) The introduction of ICT has improved the banking services.

3) ICT tools have reduced the longtime delay spent of queues by customers.

4) ICT has witnessed a positive change in the employment scenario.

\section{Summary of Findings:}

The following findings were made in the study:

Firstly, the positive impact of the application of ICT in the banking industry cannot be overemphasized as it affects the bank, the customers and the employees. This manifest in the areas of efficiency, proficiency, reduced long time spent on queues improvements, etc.

Secondly, the adoption of ICT in Diamond Bank has some business environment, social, economic and financial implications. This is sequel to the fact Diamond Bank has now gained valuable insight into saving, speedy adoption and challenges of ICT tools.

\section{Recommendation:}

Based on the above findings, I hereby make the following recommendations:

1) Banks and other business organizations in Nigeria and the rest of world should intensify effort towards adoption of ICT to reap the numerous benefit associated there in.

2) Service providers should develop devices for monitoring the services being provided, in order to ensure high quality services while minimize the adverse business implications of ICT.

3) The Bank management should always ensure that staffs are given adequate training on the use and maintenance of these tools. The software and hardware should be adequately maintained.

\section{References}

[1] Margaret Rouse (2005) ICT (Information and Communications Technology). http://searchcio.techtarget.com/definition/ICT-information-and-communications-t echnology-or-technologies

[2] https://en.wikipedia.org/wiki/Information_technology

[3] Ekwonwune, E. and Dike, J. (2006) The Role of Information Technology in the Employment Generation Using UBA as a Case. An Unpublished MSC Thesis, Department of Computer Science, Imo State University, Owerri.

[4] Landon, D. and Landon, J. (1991) Business Information System: A Problem Solving Approach. HBJ, College Publishers, New York.

[5] Hassan, G. (1998) Information Tech in the Banking Sector: Opportunities, Threats and Strategies. Graduate School of Business and Management, American University of Beirut, Beirut.

[6] Rahman, I. (2007) Role of Information Technology in Banking Industry. Review of Business Research, 7.

[7] Remmy, N. (2008) e-Transact, Bank and Future of e-payment in Africa. http://www.itrealms.com.ng/2008_07_01_archive.html

[8] Ekezie, D. (2001) Statistics for Sciences and Businesses. Kricel Books Ltd., PortHarcourt.

[9] Nworgu (2006) Educational Research: Basic and Methodology. University Trust Publisher, Nigeria. 
Submit or recommend next manuscript to SCIRP and we will provide best service for you:

Accepting pre-submission inquiries through Email, Facebook, LinkedIn, Twitter, etc. A wide selection of journals (inclusive of 9 subjects, more than 200 journals)

Providing 24-hour high-quality service

User-friendly online submission system

Fair and swift peer-review system

Efficient typesetting and proofreading procedure

Display of the result of downloads and visits, as well as the number of cited articles Maximum dissemination of your research work

Submit your manuscript at: http://papersubmission.scirp.org/

Or contact jec@scirp.org 